\title{
Seed Yield Potential of Five Wheat Species/Cultivars without and with Phosphorus Fertilizer Application on a P-Deficient Soil in Northeastern Saskatchewan
}

\author{
Sukhdev S. Malhi1 ${ }^{1,2}$, Cecil L. Vera ${ }^{1 *}$, Stewart A. Brandt ${ }^{2}$ \\ ${ }^{1}$ Agriculture and Agri-Food Canada, Melfort, Canada \\ ${ }^{2}$ Northeast Agricultural Research Foundation, Melfort, Canada \\ Email: ${ }^{*}$ cecil.vera@agr.gc.ca
}

Received 26 January 2015; accepted 9 February 2015; published 16 February 2015

Copyright (C) 2015 by authors and Scientific Research Publishing Inc.

This work is licensed under the Creative Commons Attribution International License (CC BY). http://creativecommons.org/licenses/by/4.0/

\section{(c) (i) Open Access}

\section{Abstract}

In the Canadian Prairies, many soils on organic farms are low in available phosphorus (P). Previous research has shown that wheat species/cultivars vary in their sensitivity to $P$ deficiency, yield response to applied $P$ fertilizer, $P$ uptake and $P$ use efficiency on P-deficient soils. A 3-year field experiment was conducted from 2012 to 2014 on a P-deficient soil at Kelvington, Saskatchewan, Canada, to determine the potential of five wheat species/cultivars (Spelt and Kamut representing "ancient", Red Fife representing "old", and Unity and Goodeve representing "modern" wheat species/cultivars) for seed yield, protein concentration (PC) in seed, partial factor of productivity

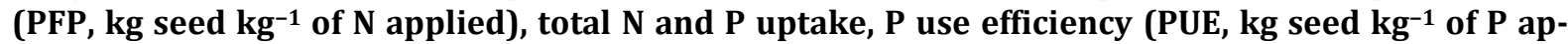
plied) and \% recovery of applied $P$ in seed under zero- $P$ and with $P$ fertilizer (triple superphosphate) applied at $20 \mathrm{~kg} \mathrm{P} \mathrm{ha}^{-1}$. Seed yield, PFP and PUE were determined in all 3 years, but PC, total $\mathrm{N}$ and $\mathrm{P}$ uptake, and \% recovery of applied $\mathrm{P}$ in seed were determined only in 2012 . There was a marked and significant response of seed yield and PFP of all wheat species/cultivars to $P$ fertilizer in all 3 years, but the actual seed yield and PFP, without and with applied $P$ fertilizer, as well as PUE, varied with species/cultivar in different years. On the average of 3 years, seed yield and PFP were greatest for Unity in both without and with applied $P$ fertilizer treatments. Seed yield increases from applied $P$ were 1111, 773, 890, 1810 and $2028 \mathrm{~kg}^{\cdot \mathrm{ha}^{-1}}$, respectively, for Spelt, Kamut, Red Fife, Unity and Goodeve. Total $N$ and $P$ uptake were lowest for Kamut and greatest for Unity or Goodeve, in both without and with applied $P$ fertilizer treatments. Percent recovery of

\footnotetext{
*Corresponding author.
} 
applied $P$ in seed was greatest for Goodeve or Unity and lowest for Spelt or Kamut. Protein concentration in seed usually decreased with $P$ fertilizer, and wheat species/cultivars with higher PC in seed usually showed greater reduction in PC with $P$ application. In conclusion, the findings suggest that the "modern" wheat species/cultivars Unity or Goodeve might be more suitable for high sustainable seed yield and total P or $\mathrm{N}$ uptake than the "ancient" wheat species Spelt and Kamut or the "old" wheat cultivar Red Fife, especially when adequate amount of $P$ fertilizer is applied to optimize crop production on a P-deficient soil.

\section{Keywords}

Cultivars, P-Deficient Soil, P Fertilizer, Seed Yield, Total N Uptake, Total P Uptake, Wheat

\section{Introduction}

In the Canadian Prairies, most soils on organic farms are deficient in available nitrogen $(\mathrm{N})$, many soils are low in available phosphorus (P), and some soils (mostly in the Parkland region) contain insufficient amounts of available sulphur (S) for optimum crop yields. It is well known that any nutrient limiting in soil can cause substantial reduction in crop yield. On organic farms, the deficiency of $\mathrm{N}$ in soil/crop can be prevented by growing $\mathrm{N}$-fixing legume crops in the rotations, and deficiency of $\mathrm{S}$ by applying gypsum. However, if soils are deficient in available $\mathrm{P}$, the only alternative is to use external sources to prevent $\mathrm{P}$ deficiency. Manure can provide this nutrient, but usually there is not enough manure to apply on all farm fields, particularly in remote areas because of the high cost of transporting manure long distances. On P-deficient soils, rock phosphate fertilizer, wood ash (waste product of industry), bone meal ash and microbial inoculants/products (JumpStart ${ }^{\circledR}$-Penicillium bilaiae and MYKE ${ }^{\circledR}$ PRO) have been suggested to be used as sources of $\mathrm{P}$ to correct $\mathrm{P}$ deficiency. However, in a 3-year study on a P-deficient soil in northeastern Saskatchewan, Malhi et al. [1] found that rock phosphate fertilizer, Penicillium bilaiae or MykePro were not very effective in preventing/correcting P deficiency in barley even after three consecutive annual applications, while there was a limited success from wood ash and bone meal ash. Thus, further research is needed to investigate other new techniques to prevent P deficiency in crops on organic farms.

Recent research in Pakistan has shown that wheat species/cultivars vary in their sensitivity to P deficiency, their response of seed, shoot or root yield to applied P fertilizer, P uptake, P use efficiency, and P harvest, utilization, absorption or physiology efficiency indices on P-deficient soils [2]-[5]. However, the information on the potential of wheat species/cultivars in tolerating $\mathrm{P}$ deficiency is lacking in Canada, especially under prairie soilclimatic conditions. The objective of the study was to determine the potential of five wheat species/cultivars (Spelt and Kamut representing "ancient”, Red Fife representing "old”, and Unity and Goodeve representing "modern" wheat species/cultivars) for seed yield, protein concentration (PC) in seed, partial factor of productivity (PFP, $\mathrm{kg}$ seed $\mathrm{kg}^{-1}$ of $\mathrm{N}$ applied), total $\mathrm{N}$ and $\mathrm{P}$ uptake, $\mathrm{P}$ use efficiency (PUE, $\mathrm{kg}$ seed $\mathrm{kg}^{-1}$ of $\mathrm{P}$ applied), and \% recovery of applied $\mathrm{P}$ in seed under zero-P and with $\mathrm{P}$ fertilizer (triple superphosphate at $20 \mathrm{~kg} \mathrm{P} \mathrm{ha}^{-1}$ ).

\section{Materials and Methods}

A 3-year (2012 to 2014) field experiment was established in spring 2012 on a thin Black Chernozem (TypicCryoboroll) loam soil near Kelvington, Saskatchewan, Canada. Soil at this site has shown severe P deficiency in alfalfa, as forage yield of alfalfa increased dramatically with P fertilizer application in 2011 (S. S. Malhi-personal communication). Some characteristics of soils used in this experiment are presented in Table 1. For characterization, a soil sample (composite of eight $2.4 \mathrm{~cm}$ diameter cores) was taken from the experimental area in spring 2012. After drying at room temperature, the soil samples were ground to pass through a 2-mm sieve and then analyzed for various soil characteristics at the Soil Testing Laboratory of Agriculture and Agri-Food Canada Research Centre, Swift Current, Saskatchewan, Canada. Precipitation in the growing season (May, June, July and August) at the nearest Environment Canada Meteorological Station (Yorkton, Saskatchewan) is given in Table 2.

In this experiment, a randomized complete block design was used to lay out the treatments in four replications, with plot dimension of $7.5 \mathrm{~m}$ long and $1.8 \mathrm{~m}$ wide. The 10 treatments consisted of $5 \times 2$ factorial, with five 
Table 1. Some characteristics of soil in spring 2012 at initiation of the field experiment with five wheat species/cultivars and two rates of $\mathrm{P}$ fertilizer at Kelvington, Saskatchewan.

\begin{tabular}{|c|c|c|c|c|c|c|c|c|}
\hline $\begin{array}{l}\text { Soil Great } \\
\text { Group }^{\mathrm{Z}}\end{array}$ & $\begin{array}{l}\text { Depth } \\
\text { (cm) }\end{array}$ & Texture & $\begin{array}{c}\text { Organic } \\
\text { matter (\%) }\end{array}$ & $\begin{array}{c}\mathrm{pH} \\
\text { (1:2 water) }\end{array}$ & $\begin{array}{c}\text { Nitrate-N } \\
\left(\mathrm{kg} \cdot \mathrm{ha}^{-1}\right)\end{array}$ & $\begin{array}{c}\text { Extractable P } \\
\left(\mathrm{kg} \cdot \mathrm{ha}^{-1}\right)\end{array}$ & $\begin{array}{c}\mathrm{SO}_{4}-\mathrm{S} \\
\left(\mathrm{kg} \cdot \mathrm{ha}^{-1}\right)\end{array}$ & $\begin{array}{c}\text { Extractable K } \\
\left(\mathrm{kg} \cdot \mathrm{ha}^{-1}\right)\end{array}$ \\
\hline Black chernozem (thin) & $0-30$ & & 4.0 & 7.8 & 12.3 & 3.4 & 10.1 & 773 \\
\hline
\end{tabular}

${ }^{\mathrm{z}}$ Based on Canadian soil classification system.

Table 2. Growing season monthly and total precipitation for the three site-years, and average 30-yr average precipitation and temperature near Kelvington, Saskatchewan.

\begin{tabular}{cccccc} 
& \multicolumn{3}{c}{ Precipitation in the growing season $(\mathrm{mm})^{\mathrm{z}}$} & \multicolumn{2}{c}{ 30-yr average } \\
\hline Month & 2012 & 2013 & 2014 & Precipitation $(\mathrm{mm})$ & Temperature $\left({ }^{\circ} \mathrm{C}\right)$ \\
May & 93.4 & 19.1 & 45.5 & 48.3 & 10.4 \\
June & 112.8 & 50.1 & 235.0 & 79.9 & 15.5 \\
July & 61.6 & 64.9 & 21.5 & 78.2 & 17.9 \\
August & 16.4 & 9.1 & 86.8 & 62.2 & 17.1 \\
Total & 284.2 & 143.5 & 388.8 & 268.6 & \\
\hline
\end{tabular}

${ }^{\mathrm{z}}$ At the nearest environment Canada meteorological station (Yorkton, Saskatchewan).

wheat species/cultivars (Spelt [Triticum spelta L.], Kamut [Triticum turanicum Jakubz.], Red Fife [Triticum aestivum L.], Unity VB [Triticum aestivum L.] and Goodeve VB [Triticum aestivum L.]) being the first factor and two P levels ( $0 \mathrm{~kg} \mathrm{P} \mathrm{ha}^{-1}$ and $\left.20 \mathrm{~kg} \mathrm{P} \mathrm{ha}^{-1}\right)$ the second. In the spring of 2012, 2013 and 2014, all plots received a blanket application (surface-broadcast) of $\mathrm{N}$ (34-0-0 at $120 \mathrm{~kg} \mathrm{~N} \mathrm{ha}^{-1}$ ) and S $\left(\mathrm{K}_{2} \mathrm{SO}_{4}\right.$ at $20 \mathrm{~kg} \mathrm{~S} \mathrm{ha}^{-1}$ ), and were then tilled to incorporate fertilizers just prior to seeding. The $\mathrm{P}$ treatments had triple superphosphate (0-45-0) side-banded at seeding every year. Plots were seeded with a double-disc press drill with $17.8 \mathrm{~cm}$ row spacing. Weeds were controlled by using appropriate herbicides in every growing season.

For each plot, seed yield data were recorded in all 3 years, while data collection on concentration and uptake of total $\mathrm{P}$ and $\mathrm{N}$ in the seed was performed only in 2012. Seed yield was determined by harvesting $1.25 \mathrm{~m}$ wide and $7.0 \mathrm{~m}$ long strips with a plot combine at maturity. Total $\mathrm{P}$ in finely-ground seed samples (oven-dried at $60^{\circ} \mathrm{C}$ ), which were digested in a mixture of acids (reagent grade $\mathrm{HNO}_{3}, \mathrm{HClO}_{4}, \mathrm{H}_{2} \mathrm{SO}_{4}, \mathrm{HCl}$ and $\mathrm{H}_{2} \mathrm{O}_{2}$ ), was measured by using ICP-AES (Atomic Emission Spectroscopy) method of Huang and Schulte [6]). Total $\mathrm{N}$ in seed samples (oven-dried at $60^{\circ} \mathrm{C}$ ) was determined by sample digestion and detection of $\mathrm{N}$ by thermal conductivity using a CNS combustion analyzer [7]. Total $\mathrm{P}$ or $\mathrm{N}$ uptake, expressed in $\mathrm{kg} \mathrm{P} \mathrm{ha}^{-1}$ or kg N ha ${ }^{-1}$, was calculated by multiplying the concentrations of total $\mathrm{P}$ or total $\mathrm{N}$ with yields of seed. Protein concentration (PC) was calculated by multiplying the total $\mathrm{N}$ with 6.25 [8].

Partial factor of productivity (PFP-kg seed $\mathrm{kg}^{-1}$ applied $\mathrm{N} \mathrm{ha}^{-1}$ ), $\mathrm{P}$ use efficiency (PUE-increase in $\mathrm{kg}$ seed $\mathrm{kg}^{-1}$ applied $\mathrm{P} \mathrm{ha}^{-1}$ ) and percent recovery of applied $\mathrm{P}$ in seed (\%) were also calculated and used to compare the various $\mathrm{P}$ treatments. Partial factor productivity was calculated as: [seed yield in $\mathrm{kg} \cdot \mathrm{ha}^{-1}$ in a treatment]/[rate of applied $\mathrm{N}$ in $\mathrm{kg} \cdot \mathrm{N} \cdot \mathrm{ha}^{-1}$ ] [9]. Phosphorus use efficiency (PUE) was calculated as: [seed yield in $\mathrm{kg} \mathrm{ha}^{-1}$ in the P fertilized treatment-seed yield in $\mathrm{kg} \cdot \mathrm{ha}^{-1}$ in the zero-P control]/[rate of applied $\mathrm{P}$ in $\mathrm{kg} \cdot \mathrm{P} \cdot \mathrm{ha}^{-1}$ ]. Percent recovery of applied $\mathrm{P}$ in seed was calculated as: 100 [amount of total $\mathrm{P}$ in $\mathrm{kg} \mathrm{P} \mathrm{ha}^{-1}$ recovered in the $\mathrm{P}$ fertilized treatment amount of total $\mathrm{P}$ in $\mathrm{kg} \cdot \mathrm{P} \cdot \mathrm{ha}^{-1}$ recovered in the zero-P control]/[rate of applied $\mathrm{P}$ in $\mathrm{kg} \cdot \mathrm{P} \cdot \mathrm{ha}^{-1}$ ].

The data were subjected to analysis of variance (ANOVA) using GLM procedure [10]. For each ANOVA, standard error of the mean (SEM) and significance are reported. Least significant difference $\left(\mathrm{LSD}_{0.05}\right)$ was used to determine significant differences between treatment means.

\section{Results and Discussion}

In 2012, the growing season precipitation was much above-average (especially in June and July during peak growing season), with relatively cooler air temperatures and wet conditions in June and July. In 2013, the growing season precipitation was slightly below-average, but it was well distributed and above-average in June and 
July during peak growing season, resulting in excellent crop growth and seed yield. In 2014, the growing season precipitation was slightly above-average.

Previous research studies have shown marked variations of wheat species/cultivars in their sensitivity to P deficiency, seed, shoot or root yield response to applied P fertilizer, P uptake and P use efficiency on P deficient soils [2]-[5] [11]. Similarly, in our study there was a marked and significant response of seed yield, PFP, and total $\mathrm{N}$ and $\mathrm{P}$ uptake of all wheat species/cultivars to $\mathrm{P}$ fertilizer in all 3 years of our present study, but the actual seed yields, PFP, and total $\mathrm{N}$ and $\mathrm{P}$ uptake without and with applied $\mathrm{P}$ fertilizer, PUE and \% recovery of applied $\mathrm{P}$ varied with species/cultivars in the different years (Tables 3-6). Seed yield, PFP and PUE were measured in all 3 years, but $\mathrm{PC}$, total $\mathrm{N}$ uptake, total $\mathrm{P}$ uptake and \% recovery of applied $\mathrm{P}$ in seed were measured only in 2012. The results of our 3-year field study on seed yield, PFP, total $\mathrm{N}$ uptake and total P uptake without and with applied P fertilizer, PUE and \% recovery of applied P are reported in detail and discussed with explanations in the following paragraphs.

Main effects of wheat species/cultivar and $\mathrm{P}$ fertilizer rate, and the interaction effects of wheat cultivar x P fertilizer rate on seed yield, PFP, protein content, total $\mathrm{N}$ uptake and total $\mathrm{P}$ uptake were significant in all 3 years. This was because of the differences in seed yield, PFP, protein content, total $\mathrm{N}$ uptake and total $\mathrm{P}$ uptake of wheat species/cultivars in without and with applied $\mathrm{P}$ fertilizer treatments in different years. For example,

Table 3. Seed yield of wheat without and with applied P on a P-deficient soil in 2012, 2013 and 2014 in a field experiment with five wheat species/cultivars and two rates of P fertilizer at Kelvington, Saskatchewan.

\begin{tabular}{|c|c|c|c|c|c|c|}
\hline \multicolumn{3}{|c|}{ Treatment } & \multicolumn{4}{|c|}{ Seed yield $\left(\mathrm{kg} \cdot \mathrm{ha}^{-1}\right)$} \\
\hline No & Wheat species/cultivar & Rate of P $\left(\mathrm{kg} \cdot \mathrm{P} \cdot \mathrm{ha}^{-1}\right)$ & 2012 & 2013 & 2014 & Mean \\
\hline 1 & Spelt & 0 & 770 & 1843 & 1204 & 1272 \\
\hline 2 & Spelt & 20 & 1161 & 3300 & 2689 & 2383 \\
\hline 3 & Kamut & 0 & 481 & 1857 & 1087 & 1142 \\
\hline 4 & Kamut & 20 & 722 & 3247 & 1775 & 1915 \\
\hline 5 & Red Fife & 0 & 904 & 1955 & 1220 & 1360 \\
\hline 6 & Red Fife & 20 & 1566 & 2997 & 2189 & 2250 \\
\hline 7 & Unity & 0 & 1017 & 2238 & 1185 & 1480 \\
\hline 8 & Unity & 20 & 2208 & 4356 & 3305 & 3290 \\
\hline 9 & Goodeve & 0 & 927 & 1831 & 374 & 1044 \\
\hline \multirow[t]{14}{*}{10} & Goodeve & 20 & 2201 & 3998 & 3017 & 3072 \\
\hline & & $\mathrm{LSD}_{0.05}$ & 246 & 344 & 477 & 231 \\
\hline & & SEM & $84.8^{* * *}$ & $118.4^{* * *}$ & $164.3^{* * *}$ & $79.7^{* * *}$ \\
\hline & Spelt & & 966 & 2572 & 1947 & 1828 \\
\hline & Kamut & & 602 & 2552 & 1431 & 1528 \\
\hline & Red Fife & & 1235 & 2476 & 1704 & 1805 \\
\hline & Unity & & 1612 & 3297 & 2245 & 2385 \\
\hline & Goodeve & & 1564 & 2915 & 1696 & 2058 \\
\hline & & $\mathrm{LSD}_{0.05}$ & 174 & 243 & 337 & 163 \\
\hline & & SEM & $60.0^{* * *}$ & $75.9^{* * *}$ & $116.2^{* * *}$ & $56.4^{* * *}$ \\
\hline & & 0 & 820 & 1945 & 1014 & 1260 \\
\hline & & 20 & 1572 & 3580 & 2595 & 2582 \\
\hline & & $\mathrm{LSD}_{0.05}$ & 110 & 154 & 213 & 103 \\
\hline & & SEM & $37.9^{* * *}$ & $53.0^{* * *}$ & $73.5^{* * *}$ & $35.6^{* * *}$ \\
\hline
\end{tabular}

\footnotetext{
${ }^{* * *}$ Refers to significant treatment effects in ANOVA at $\mathrm{P} \leq 0.001$
} 
Table 4. Partial factor of productivity (PFP, $\mathrm{kg}_{\text {seed }} \mathrm{kg}^{-1}$ of $\mathrm{N}$ applied) of seed yield of wheat without and with applied $\mathrm{P}$ on a P-deficient soil in 2012, 2013 and 2014 in a field experiment with five wheat species/cultivars and two rates of P fertilizer at Kelvington, Saskatchewan.

\begin{tabular}{|c|c|c|c|c|c|c|}
\hline \multicolumn{3}{|c|}{ Treatment } & \multicolumn{4}{|c|}{ PFP ( $\mathrm{kg}$ seed $\mathrm{kg}^{-1}$ of $\mathrm{N}$ applied) } \\
\hline No & Wheat species/cultivar & Rate of P (kg.P.ha $\left.{ }^{-1}\right)$ & 2012 & 2013 & 2014 & Mean \\
\hline 1 & Spelt & 0 & 7.7 & 18.4 & 12.0 & 12.7 \\
\hline 2 & Spelt & 20 & 11.6 & 33.0 & 26.9 & 23.8 \\
\hline 3 & Kamut & 0 & 4.8 & 18.6 & 10.9 & 11.4 \\
\hline 4 & Kamut & 20 & 7.2 & 32.5 & 17.7 & 19.1 \\
\hline 5 & Red Fife & 0 & 9.0 & 19.5 & 12.2 & 13.6 \\
\hline 6 & Red Fife & 20 & 15.7 & 30.0 & 21.9 & 22.5 \\
\hline 7 & Unity & 0 & 10.2 & 22.4 & 11.9 & 14.8 \\
\hline 8 & Unity & 20 & 22.1 & 43.6 & 33.0 & 32.9 \\
\hline 9 & Goodeve & 0 & 9.3 & 18.3 & 3.7 & 10.4 \\
\hline \multirow[t]{14}{*}{10} & Goodeve & 20 & 22.0 & 40.0 & 30.2 & 30.7 \\
\hline & & $\mathrm{LSD}_{0.05}$ & 2.5 & 3.5 & 4.8 & 2.3 \\
\hline & & SEM & $0.84^{* * *}$ & $1.19^{* * * *}$ & $1.64^{* * *}$ & $0.79^{* * *}$ \\
\hline & Spelt & & 9.7 & 25.7 & 19.5 & 18.3 \\
\hline & Kamut & & 6.0 & 25.5 & 14.3 & 15.3 \\
\hline & Red Fife & & 12.4 & 24.8 & 17.0 & 18.0 \\
\hline & Unity & & 16.1 & 33.0 & 22.5 & 23.8 \\
\hline & Goodeve & & 15.6 & 29.1 & 17.0 & 20.6 \\
\hline & & $\mathrm{LSD}_{0.05}$ & 1.7 & 2.4 & 3.4 & 1.6 \\
\hline & & SEM & $0.60^{* * *}$ & $0.84^{* * *}$ & $1.16^{* * *}$ & $0.56^{* * *}$ \\
\hline & & 0 & 8.2 & 19.4 & 10.1 & 12.6 \\
\hline & & 20 & 15.7 & 35.8 & 25.9 & 25.8 \\
\hline & & $\mathrm{LSD}_{0.05}$ & 1.1 & 1.5 & 2.1 & 1.0 \\
\hline & & SEM & $0.38^{* * *}$ & $0.53^{* * * *}$ & $0.73^{* * *}$ & $0.35^{* * *}$ \\
\hline
\end{tabular}

\footnotetext{
${ }^{* * *}$ Refers to significant treatment effects in ANOVA at $\mathrm{P} \leq 0.001$.
}

“ancient” wheat species/cultivars usually yielded lower than "modern” wheat species/cultivars under adequate $\mathrm{P}$ (applied P) condition in all 3 years. However, under low P (without applied P) condition, "ancient” wheat species/cultivars yielded lower than "modern" wheat species/cultivars in 2012 but there was no consistent trend/ pattern in 2013 and 2014. Without applied P, Goodeve had seed yield similar to Spelt or Kamut in 2013 but it was lowest in 2014. There is no real explanation for this very low seed yield of Goodeve in 2014.

Unity had the greatest seed yield and PFP in both without and with applied P fertilizer in all 3 years (Table 3 and Table 4). Seed yield increases from applied P for Spelt, Kamut, Red Fife, Unity and Goodeve, respectively, were 391, 241, 662, 1191 and $1274 \mathrm{~kg} \cdot \mathrm{ha}^{-1}$ in 2012, 1457, 1390, 1042, 2118 and $2157 \mathrm{~kg} \cdot \mathrm{ha}^{-1}$ in 2013, and 1485, 688, 969, 2120 and $2643 \mathrm{~kg} \cdot \mathrm{ha}^{-1}$ in 2014. The corresponding values for increase in PFP from applied P for Spelt, Kamut, Red Fife, Unity and Goodeve, respectively, were 3.2, 2.0, 5.8, 9.9 and $10.6 \mathrm{~kg}$ seed kg $\mathrm{kg}^{-1} \mathrm{~N}$ applied ha ${ }^{-1}$ in 2012, 11.9, 11.6, 8.7, 17.6 and $18.0 \mathrm{~kg}$ seed $\mathrm{kg}^{-1}$ of $\mathrm{N}$ applied ha ${ }^{-1}$ in 2013, and 14.9, 6.8, 9.7, 21.1 and $26.5 \mathrm{~kg}$ seed $\mathrm{kg}^{-1}$ of $\mathrm{N}$ applied ha ${ }^{-1}$ in 2014. On averaged across wheat cultivars, the increase in seed yield and PFP from applied P, respectively, was $752 \mathrm{~kg} \cdot \mathrm{ha}^{-1}$ and $6.2 \mathrm{~kg} \mathrm{seed} \mathrm{kg}^{-1}$ of N applied ha ${ }^{-1}$ in 2012, $1635 \mathrm{~kg} \cdot \mathrm{ha}^{-1}$ and $13.6 \mathrm{~kg}$ seed kg ${ }^{-1}$ of $\mathrm{N}$ applied ha ${ }^{-1}$ in 2013 , and $1581 \mathrm{~kg} \cdot \mathrm{ha}^{-1}$ and $15.8 \mathrm{~kg}$ seed kg ${ }^{-1}$ of $\mathrm{N}$ applied $\mathrm{ha}^{-1}$ in 2014. The values for PUE for Spelt, Kamut, Red Fife, Unity and Goodeve, respectively, were 19.6, 12.1, 
Table 5. Protein concentration(g PC kg $\left.{ }^{-1}\right)$, total P uptake $\left(\mathrm{kg} \mathrm{P} \mathrm{ha}^{-1}\right)$ and total $\mathrm{N}$ uptake $\left(\mathrm{kg} \mathrm{N} \mathrm{ha}^{-1}\right)$ in seed of wheat without and with applied P on a P-deficient soil in 2012 in a field experiment with five wheat species/cultivars and two rates of P fertilizer at Kelvington, Saskatchewan.

\begin{tabular}{|c|c|c|c|c|c|}
\hline \multicolumn{3}{|c|}{ Treatment } & \multicolumn{3}{|c|}{ g $\mathrm{PC} \mathrm{kg}{ }^{-1}$ or $\mathrm{kg} \mathrm{P}$ or $\mathrm{N} \mathrm{ha}^{-1}$} \\
\hline No & Wheat species/cultivar & Rate of $\mathrm{P}\left(\mathrm{kg} \mathrm{P} \mathrm{ha}^{-1}\right)$ & PC & P uptake & $\mathrm{N}$ uptake \\
\hline 1 & Spelt & 0 & 181 & 2.55 & 23.8 \\
\hline 2 & Spelt & 20 & 168 & 4.63 & 33.3 \\
\hline 3 & Kamut & 0 & 205 & 1.68 & 16.7 \\
\hline 4 & Kamut & 20 & 184 & 3.55 & 22.8 \\
\hline 5 & Red Fife & 0 & 146 & 2.47 & 22.6 \\
\hline 6 & Red Fife & 20 & 147 & 5.65 & 39.1 \\
\hline 7 & Unity & 0 & 178 & 3.43 & 30.8 \\
\hline 8 & Unity & 20 & 166 & 8.93 & 62.8 \\
\hline 9 & Goodeve & 0 & 189 & 3.00 & 30.0 \\
\hline \multirow[t]{14}{*}{10} & Goodeve & 20 & 168 & 9.15 & 63.0 \\
\hline & & $\operatorname{LSD}_{0.05}$ & 7 & 1.39 & 7.6 \\
\hline & & SEM & $2.4^{* * *}$ & $0.479^{* * *}$ & $2.61^{* * *}$ \\
\hline & Spelt & & 174 & 3.59 & 28.6 \\
\hline & Kamut & & 195 & 2.61 & 19.8 \\
\hline & Red Fife & & 147 & 4.06 & 30.8 \\
\hline & Unity & & 172 & 6.18 & 46.8 \\
\hline & Goodeve & & 179 & 6.08 & 46.5 \\
\hline & & $\mathrm{LSD}_{0.05}$ & 5 & 0.98 & 5.3 \\
\hline & & SEM & $1.7^{* * *}$ & $0.339^{* * *}$ & $1.84^{* * *}$ \\
\hline & & 0 & 180 & 2.62 & 24.8 \\
\hline & & 20 & 167 & 6.38 & 44.2 \\
\hline & & $\mathrm{LSD}_{0.05}$ & 3 & 0.62 & 3.4 \\
\hline & & SEM & $1.1^{* * *}$ & $0.214^{* * *}$ & $1.16^{* * *}$ \\
\hline
\end{tabular}

**** Refers to significant treatment effects in ANOVA at $\mathrm{P} \leq 0.001$.

Table 6. Phosphorus use efficiency (PUE, $\mathrm{kg}$ seed $\mathrm{kg}^{-1}$ of $\mathrm{P}$ applied) of seed yield of wheat with $20 \mathrm{~kg}^{\mathrm{P}}$ ha ${ }^{-1}$ applied on a P-deficient soil in 2012, 2013 and 2014 and percent recovery of applied P (\%) in 2012 in a field experiment with five wheat species/cultivars and two rates of $\mathrm{P}$ fertilizer at Kelvington, Saskatchewan.

\begin{tabular}{|c|c|c|c|c|c|}
\hline \multirow{2}{*}{$\begin{array}{c}\text { Treatment } \\
\text { Wheat species/cultivar }\end{array}$} & \multicolumn{4}{|c|}{ PUE (kg seed $\mathrm{kg}^{-1}$ of $\mathrm{P}$ applied) } & \multirow{2}{*}{\begin{tabular}{|c|} 
Recovery of applied P (\%) \\
2012
\end{tabular}} \\
\hline & 2012 & 2013 & 2014 & Mean & \\
\hline Spelt & 19.6 & 72.9 & 74.2 & 55.6 & 10.3 \\
\hline Kamut & 12.1 & 69.5 & 34.4 & 38.7 & 9.4 \\
\hline Red Fife & 33.1 & 52.1 & 48.5 & 44.5 & 15.9 \\
\hline Unity & 59.6 & 105.9 & 106.0 & 90.5 & 27.4 \\
\hline Goodeve & 63.7 & 108.4 & 132.2 & 101.4 & 30.7 \\
\hline $\mathrm{LSD}_{0.05}$ & 20.8 & 21.8 & 31.2 & 15.0 & 11.5 \\
\hline SEM & $6.75^{* * *}$ & $7.06^{* * *}$ & $10.11^{* * *}$ & $4.88^{* * *}$ & $3.73^{* *}$ \\
\hline
\end{tabular}

${ }^{* *}$ and ${ }^{* * *}$ refer to significant treatment effects in ANOVA at $\mathrm{P} \leq 0.01$ and $\mathrm{P} \leq 0.001$, respectively. 
33.1, 59.6 and $63.7 \mathrm{~kg}$ seed $\mathrm{kg}^{-1}$ of P applied ha ${ }^{-1}$ in 2012, 72.9, 105.9, 108.4, 69.5 and $52.1 \mathrm{~kg}^{-1}$ seed $\mathrm{kg}^{-1}$ of P applied ha ${ }^{-1}$ in 2013, and 74.2, 34.4, 48.5, 106.0 and $132.2 \mathrm{~kg}$ seed kg $^{-1}$ of P applied ha ${ }^{-1}$ in 2014 (Table 6).

Protein concentration in wheat seed (which was measured only in 2012) decreased with P fertilization, but the magnitude of decrease varied with species/cultivar (Table 5). The decrease in PC in seed from applied P fertilizer was greatest for Kamut and Goodeve, followed by Spelt and Unity, with no effect for Red Fife. Protein concentrations in wheat seed in both without and with applied P treatments suggest that the species/cultivars with higher PC in seed showed greater reduction in PC with P application. This decrease in PC in seed with P fertilization was most likely because of dilution effect from the increase in seed yield with applied P fertilizer.

Total N and P uptake in seed (which were also measured only in 2012) were lowest for Kamut, while Unity or Goodeve had the greatest total $\mathrm{N}$ and $\mathrm{P}$ uptake in both without and with applied P fertilizer (Table 5). The values were 9.5, 6.1, 16.5, 32.0 and $33.0 \mathrm{~kg} \mathrm{~N}$ ha $^{-1}$ for increase in total $\mathrm{N}$ uptake in seed from applied $\mathrm{P}, 2.08,1.87$, 2.18, 5.50 and $6.15 \mathrm{~kg} \mathrm{P} \mathrm{ha}^{-1}$ for increase in total $\mathrm{P}$ uptake in seed from applied $\mathrm{P}$, respectively, for Spelt, Kamut, Red Fife, Unity and Goodeve. When averaged across wheat species/cultivars, the increase in total $\mathrm{N}$ and $\mathrm{P}$ uptake from applied P was $19.4 \mathrm{~kg} \mathrm{~N} \mathrm{ha}^{-1}$ and $3.76 \mathrm{~kg} \mathrm{P} \mathrm{ha}^{-1}$, respectively. The values for \% recovery of applied P in seed were $10.4 \%, 9.7 \%, 15.9 \%, 27.5 \%$ and $29.3 \%$, respectively, for Spelt, Kamut, Red Fife, Unity and Goodeve (Table 6).

Other researchers have also shown marked variations of wheat species/cultivars in their sensitivity to P deficiency vary in their sensitivity to P deficiency, seed and shoot yield response to applied P fertilizer, P uptake and P use efficiency in Pakistan [2]-[4] [11]. However, in those studies seed yields of some wheat species/cultivars without applied $\mathrm{P}$ were high and also were fairly close to the seed yields of other wheat species/cultivars receiving $\mathrm{P}$ fertilizer, but this did not happen in our present study. This may be because of the differences in wheat genotypes, soil type, climatic and/or crop growing conditions, resulting in different yield potential and responses to applied P fertilizer of wheat species/cultivars in our study and previously reported research.

\section{Conclusion}

There was a marked and significant response of seed yield and PFP of all wheat species/cultivars to applied P fertilizer in all 3years, but the actual seed yield and PFP without and with applied P fertilizer, PUE and \% recovery of applied P varied with species/cultivar in different years. Our findings suggest that "modern" wheat species/cultivars Unity or Goodeve might be more suitable for high sustainable seed yield and total P or N uptake than the "ancient" wheat species Spelt and Kamut or the "old" wheat cultivar Red Fife, particularly when adequate amount of $\mathrm{P}$ fertilizer is applied to optimize crop production on a P-deficient soil.

\section{Acknowledgements}

The authors thank D. Leach and K. Strukoff for technical help.

\section{References}

[1] Malhi, S.S., Vera, C.L. and Brandt, S.A. (2014) Feasibility of Rock Phosphate and Other Amendments in Preventing P Deficiency in Barley on a P-Deficient Soil in Northeastern Saskatchewan. Agricultural Sciences, 14, 1491-1500. http://dx.doi.org/10.4236/as.2014.514160

[2] Yaseen, M. and Malhi, S.S. (2009) Differential Growth Response of 15 Wheat Genotypes for Grain Yield and P Uptake on a Low P Soil without and with Applied P Fertilizer. Journal of Plant Nutrition, 32, 1015-1043. http://dx.doi.org/10.1080/01904160902872818

[3] Yaseen, M. and Malhi, S.S. (2009) Variation in Yield, Phosphorus Uptake and Physiological Efficiency of Wheat Genotypes at Adequate and Stress Phosphorus Levels in Soil. Communications in Soil Science and Plant Analysis, 40, 3104-3120. http://dx.doi.org/10.1080/00103620903261643

[4] Yaseen, M. and Malhi, S.S. (2010) Selection Criteria for P Efficient Wheat Genotypes and Identification of Plant Characters Responsible for High Grain Yield under Low Soil P Conditions. Communications in Soil Science and Plant Analysis, 41, 679-695. http://dx.doi.org/10.1080/00103620903563923

[5] Yaseen, M. and Malhi, S.S. (2011) Exploitation of Genetic Variability among Wheat Genotypes for Tolerance to Phosphorus Deficiency Stress. Journal of Plant Nutrition, 34, 665-699. http://dx.doi.org/10.1080/01904167.2011.540623

[6] Huang, C.L. and Schulte, E.E. (1985) Digestion of Plant Tissue for Analysis by ICP Emission Spectroscopy. Commu- 
nications in Soil Science and Plant Analysis, 16, 943-958. http://dx.doi.org/10.1080/00103628509367657

[7] Association of Official Analytical Chemists (AOAC) (1995) Protein (Crude) in Animal Feed. Combustion Method (990.03). Official Methods of Analysis. 16th Edition, AOAC, Washington DC.

[8] Williams, P., Sobering, D. and Antoniszyn, J. (1998) Protein Testing Methods. In: Fowler, D.B., Geddes, W.E., Johnston, A.M. and Preston, K.R., Eds., Wheat Protein Production and Marketing, University Extension Press, University of Saskatchewan, Saskatoon, 37-47.

[9] Snyder, C.S. and Bruulsema, T.W. (2007) Nutrient Use Efficiency and Effectiveness in North America. Indices of Agronomic and Environmental Benefits. IPNI publication Ref. \# 07076, International Plant Nutrient Institute, Norcross.

[10] SAS Institute, Inc. (2004) Online Documentation for SAS, Version 8. http://support.sas.com/documentation/onlinedoc/index.html

[11] Yaseen, M. and Malhi, S.S. (2009) Differential Growth Response of Wheat Genotypes to Ammonium Phosphate and Rock Phosphate Phosphorous Sources. Journal of Plant Nutrition, 32, 410-432.

http://dx.doi.org/10.1080/01904160802660735 
Scientific Research Publishing (SCIRP) is one of the largest Open Access journal publishers. It is currently publishing more than 200 open access, online, peer-reviewed journals covering a wide range of academic disciplines. SCIRP serves the worldwide academic communities and contributes to the progress and application of science with its publication.

Other selected journals from SCIRP are listed as below. Submit your manuscript to us via either submit@scirp.org or Online Submission Portal.
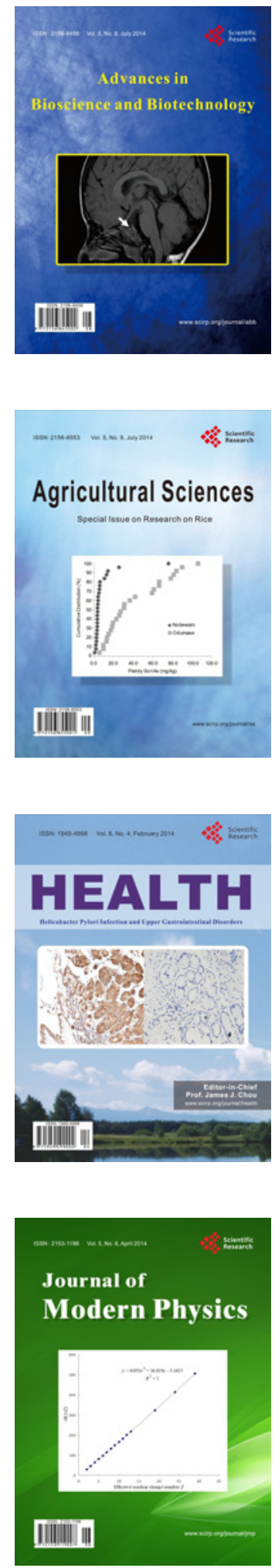
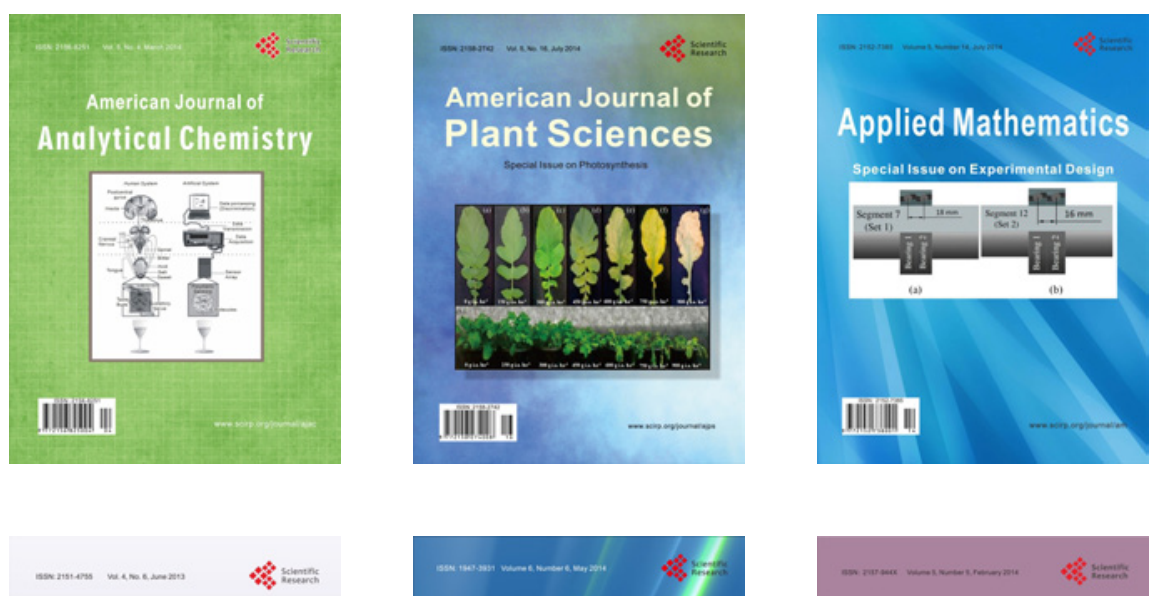

Creative Education
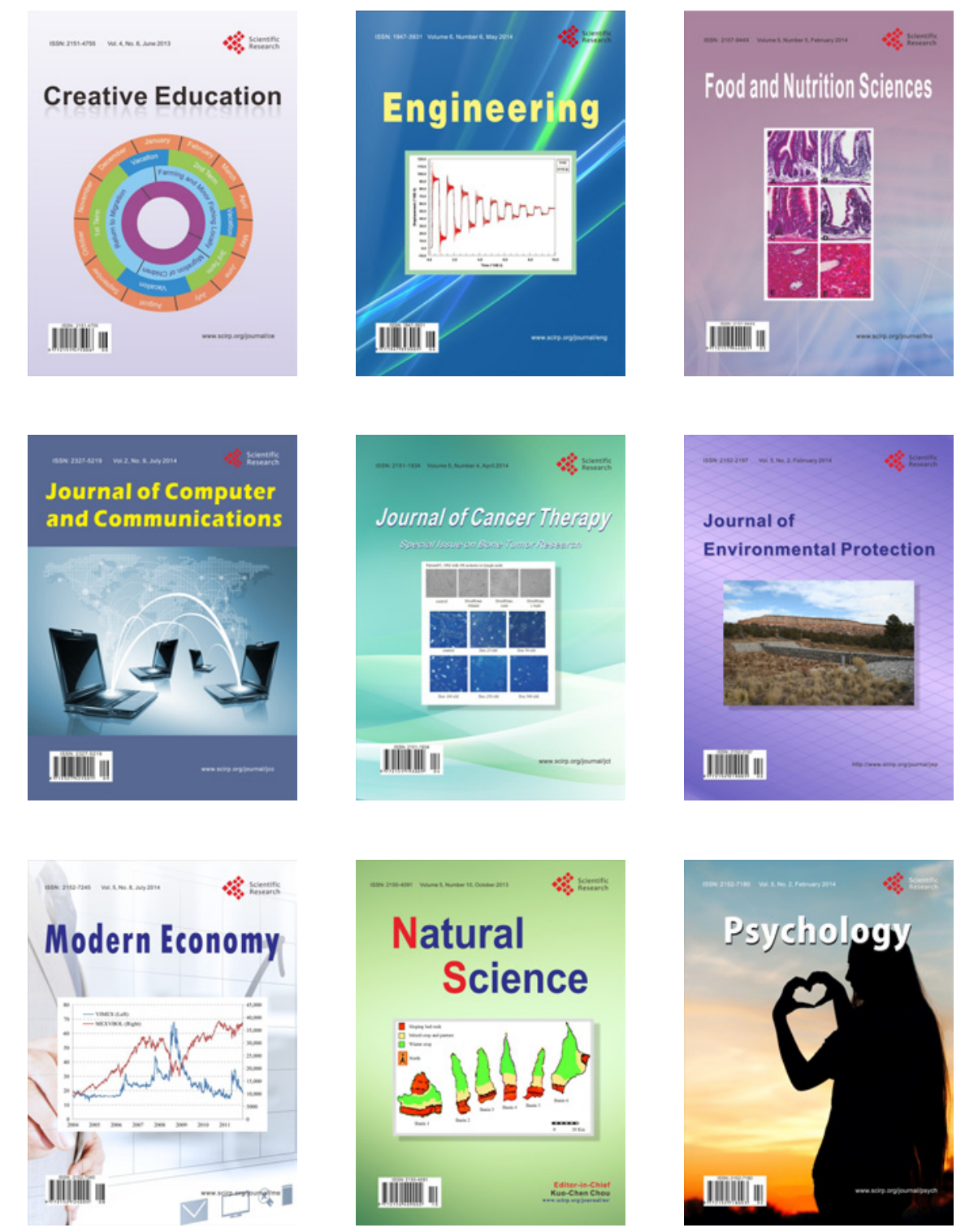